\author{
Katarzyna Tomaszek \\ Agnieszka Suchacka-Cymerman \\ Katedra Psychologii, Uniwersytet Pedagogiczny im. KEN w Krakowie
}

\title{
Zastosowanie skali ESSBS w badaniach uczniów ze szkół podstawowych
}

Artykuł dotyczy problematyki wypalenia szkolnego uczniów ze szkół podstawowych. Głównym celem prowadzonych analiz jest walidacja skali wypalenia ESSBS w tej grupie wiekowej. W badaniach wykorzystano skalę ESSBS, skalę TAB oraz Arkusz Personalny. Łącznie przebadano 144 uczniów z klas V i VI szkół podstawowych w wieku 11 lat. Przeprowadzone analizy statystycznych potwierdzają przydatność skali ESSBS w badaniach uczniów ze szkół podstawowych. Skala cechuje się wysoką zgodnością wewnętrzną $(\alpha=.87)$ i dobrą trafnością. W badanej grupie prawie połowa osób doświadczała wypalenia. W grupie uczniów wyłoniono dwa typy wypalenia: Uczniowie niedopasowani do wymagań ze strony szkoły i rodzicóworaz Uczniowie z silnym poczuciem wyczerpania. Wyniki analiz korelacyjnych potwierdzają, że uczniowie wypaleni prezentują wyższe wskaźniki Wzoru Zachowania typu A, z nasilonym pośpiechem i wrogością.

Słowa kluczowe: wypalenie szkolne, wzór zachowania typu A, nastolatkowie

\section{Application of the ESSBS scale to primaryschoolstudents}

The article presents the issue of school burn out of primary school pupils. The main goal of the conducted analyzes is to validate the scale of ESSBS burn out in this age group.The studies used the ESSBS scale, the TAB scale and the Personnel questionnaire. In total, 144 students from grades $\mathrm{V}$ and VI at the age of 11 were examined. The statistical analyzes carried out confirm the use fulness of the ESSBS scale in the research of primary school pupils. The scale is characterized by high internal consistency $(\alpha=.87)$ and good accuracy. In the study group, almost half of the people experienced burn out. In the group of students, two types of burn out were selected: Students mismat ched to the requirements of the school and parents and Students with a strong sense of exhaustion. Correlation analysis results confirm that burned students present high errates of Type A Behavior Pattern, with increased haste and hostility.

Keywords: school burn out, students; type A behavior, adolescents 


\section{Wprowadzenie}

Przemiany cywilizacyjne powodują wzrost ryzyka wypalenia w zawodach usług społecznych (Sęk 2000). Dotyka ono, jak pisze A.M. Pines (2000) tylko te osoby, które są silnie zaangażowane w swoją pracę oraz charakteryzują się głęboką motywacją. Według W. Schaufeli i D. Enzmann wypalenie to „przewlekły, negatywny stan psychiczny, wywołany pracą zawodową [...], które początkowo charakteryzuje poczucie wyczerpania, a następnie zniechęcenie, zmniejszenie skuteczności działań, obniżenie motywacji oraz negatywne postawy i zachowania utrudniające przystosowanie w pracy (Kirenko i in. 2011). Syndrom wypalenia jako „powoli zaczynający się lub nagle ujawniający się stan wyczerpania cielesnego, duchowego lub uczuciowego występujący w czasie wolnym od pracy, w kręgu przyjaciól, w związku partnerskim i w rodzinie, często powiązany z awersją, mdłościami i myślami o ucieczce" jak wskazuje J. Fengler (2001) dotyczy też innych grup niż zawodowe. Najbardziej znanymi badaczkami wypalenia są C. Maslach i S.E. Jackson (1981), które zjawisko to odnoszą do grupy zawodów z misją społeczną i definiują jako zespól, który składa się z trzech wymiarów: emocjonalnego wyczerpania, depersonalizacji i zmniejszenia osobistego spełnienia. Wyczerpanie emocjonalne spowodowane jest wymaganiami i stresorami, z którymi ludzie nie mogą sobie poradzić, czują się nimi przytłoczeni. Depersonalizacja dotyczy negatywnych i cynicznych postaw wobec innych ludzi, postrzeganych jako źródła doświadczanych przez jednostkę problemów. Obniżone poczucie osobistego spełnienia wyraża się w tendencji do negatywnego postrzegania siebie i bycia niezadowolonym ze swoich osiągnięć. Przejawami wypalenia są ponadto fizyczne wyczerpanie, bezsenność, niekiedy zwiększone używanie narkotyków i alkoholu. Wypalenie powoduje mniejszą motywację i zadowolenie z pracy, utratę zdrowia, konflikty społeczne i niższą wydajność (Maslach i in. 1997).

$\mathrm{Na}$ temat wypalenia przeprowadzono wiele badań, ale stosunkowo nowym obszarem analiz jest syndrom wyczerpania sił w kontekście edukacyjnym. Pomimo coraz większej liczby badań empirycznych nadal niewiele wiadomo na temat tego zjawiska w grupie uczniów ze szkół podstawowych. Kwestią otwartą pozostaje identyfikacja uczniów z grup ryzyka. Pomimo, że wielu uczniów uznaje szkołę za miejsce silnie stresujące (Talik 2011), to jednak tylko część z nich przejawia cierpi z powodu chronicznego wypalenie.

Zdaniem Ch. Maslach (Maslach i in., 2011) czy A. Aronson (Pines 2011) syndrom wyczerpania sił jest następstwem długotrwałego i/lub powtarzającego się nadmiernego obciążenia emocjonalnego powstałego z uwagi na zbyt intensywne angażowanie się człowieka w jakąś aktywność. Dłuższy okres czasu, w którym jednostka jest zmuszona zmagać się z różnymi stresorami wzmaga ryzyko wypalenia (Kraczka 2013). 
Ustrukturowane przez C. Maslach (2000) płaszczyzny wypalenia dotyczące sfery organizacyjnej, interpersonalnej i indywidualnej można odnieść do wypalenia szkolnego uczniów. W przypadku uczniów czynnikami organizacyjnymi mogą być zbyt liczne klasy, brak możliwości indywidualizacji kształcenia, brak umiejętności organizowania czasu poświęconego na naukę w domu i inne. Jednym z istotnych czynników powodujących wypalenie szkolne uczniów jest postrzeganie przez nich środowiska szkoły (Przewłocka 2015). Percepcja klimatu klasy i szkoły ma znaczenie dla poczucia bezpieczeństwa a jeśli go brakuje, to sytuacja taka może powodować długotrwały stres, a w jego konsekwencji wypalenie. Uczniowie wyczerpani mogą popadać w gniew i agresję, co w dużym stopniu będzie powodować niewłaściwe relacje społeczne w środowisku szkolnym. Takie czynniki jak: postrzeganie przez uczniów indywidualnych cech swoich kolegów, postrzeganie siebie w kontekście własnej sytuacji i własnych problemów w szkole, niewłaściwe relacje, brak umiejętności lub niewłaściwa komunikacja uczniów pomiędzy sobą, rywalizacja o wyniki w nauce, relacja pomiędzy uczniem a nauczycielem, pomiędzy uczniem a jego rodzicami można zaliczyć do czynników interpersonalnych. Czynniki osobowościowe natomiast dotyczą cech indywidualnych ucznia np. brak poczucia własnych kompetencji, słaba odporność na stres czy zbyt silne zaangażowanie w naukę, któremu towarzyszy nadmierny perfekcjonizm.

Badania przeprowadzone przez K. Tomaszek i A. Muchacką-Cymerman (2018) miały na celu określenie predyktorów wypalenia szkolnego uczniów, związanych ze sposobem reagowania na sytuacje stresowe tj. prezentowaniem silnie rywalizacyjnych zachowań oraz różnych sposobów radzenia sobie ze stresem. W badaniach zastosowano skalę ESSBS A. Aypaya (2012) w adaptacji autorek. Dla wypalenia szkolnego kluczowe znaczenie ma subiektywna negatywna ocena wypełniania roli ucznia tj. uznawanie siebie za słabego ucznia. Analiza i interpretacja badań pozwoliła stwierdzić, że uznanie siebie za słabego ucznia, pośpiech i wrogość, niski poziom dyspozycji do aktywnego radzenia sobie ze stresem oraz dłuższy czas działania tych samych stresorów (wiek) wyjaśnią w $42 \%$ poziom wyczerpania sił $\mathrm{u}$ badanych. Czynnikiem chroniącym dzieci i młodzież przed doświadczaniem wyczerpania sił okazała się jedynie dyspozycja do aktywnego stylu radzenie sobie ze stresem. Uczniowie ze szkół podstawowych w większym stopniu odczuwali wyczerpanie sił związane z presją rodziców, niedopasowanie do wymogów szkolnych oraz brak zainteresowania szkołą. Gimnazjaliści byli bardziej wyczerpani aktywnościami szkolnymi.

W związku z niewielką ilością badań na temat wypalenia szkolnego uczniów na gruncie polskim, referowane badania miały kilka istotnych celów.

Podstawowym celem niniejszego artykułu jest prezentacja prac walidacyjnych nad zastosowaniem skali ESSBS w grupie uczniów ze szkół podstawowych. W ramach analiz sprawdzono, czy proponowany przez autora oryginalnej skali 
Ayse Aypay'a struktura czynnikowa wypalenia jest również adekwatna dla tej grupy wiekowej. Obliczono również wskaźniki rzetelności i trafności narzędzia $\mathrm{w}$ tej grupie badanych. Drugim celem referowanych badań było zbadanie poziomu wypalenia szkolnego w grupie uczniów ze szkół podstawowych. Ostatnim celem przeprowadzonych analiz było ustalenie czy grupy różniące się poziomem wypalenia szkolnego prezentują odmienne wzorce zachowania związanego z odczuwaną presją (WZA).

\section{Metody}

Skala ESSBS autorstwa A. Aypaya (2011) w adaptacji K. Tomaszek, A. Muchackiej-Cymerman (2019). Skala złożona jest z 26 pytań, na które badani odpowiadają na 4 - o stopniowej skali Likerta. Narzędzie pozwala na ocenę globalnego poziomu wypalenia szkolnego (ESSBS) i 4 jego wymiarów: Wyczerpanie Aktywnościami Szkolnymi (BSA) (12 pytań); Wypalenie związane z presją rodziców (BSF) (5 pytań);Niedopasowanie do Wymogów Szkolnych (IIS) (4 pytania); Utrata Zainteresowania Szkołą (LIS) (5 pytań). Im wyższy wynik w skali tym niższy poziom wypalenia szkolnego. W oryginalnej wersji skala służyła do badania dzieci i młodzieży. W polskiej adaptacji sprawdzono walory psychometryczne na grupie gimnazjalistów. Wyniki prac walidacyjnych wskazują na dobre parametry rzetelności oraz dobrątrafność narzędzia w badaniach młodzieży gimnazjalnej.

Skala TAB (skala typu A/B wersja DM) N. Ogińskiej-Bulik i Z. Juczyńskiego służy do pomiaru wzoru zachowania typu A (tzw. WZA, „niezdrowego stylu reagowania), czyli zespołu wzorców afektywno-behawioralnych, których przejawem jest nieustanna walka z czasem i ludźmi (Juczyński Ogińska-Bulik 2009). Zachowania typu A pojawiają się w kontekście wzmożonych wymogów stawianych jednostce przez otoczenie Friedman, Rosenman 1974). W skład skali TAB wchodzą 4 wskaźniki WZA tj. rywalizacja (R), niecierpliwość $(\mathrm{N})$, pośpiech $(\mathrm{P})$ i wrogość (W). Współczynnik zgodności wewnętrznej dla całej skali wyniósł $\alpha=$ 0,74 ; dla poszczególnych czynników rywalizacja $\alpha=0,71$, niecierpliwość $\alpha=0,55$, pośpiech $\alpha=0,54$, wrogość $\alpha=0,57$ (Juczyński Ogińska-Bulik 2009).

Ankieta Personalna służąca do zebrania podstawowych informacji o badanych uczniach tj. płeć, wiek, subiektywna ocena wypełniania roli ucznia, czas poświęcany na naukę w ciągu dnia, zainteresowania, jakość relacji z rówieśnikami oraz jakość relacji rodzinnych.

\section{Procedura badania}

Badania prowadzono na pierwszej połowie 2016 roku. Po uzyskaniu zgody od rodziców osób badanych oraz dyrekcji, uczniowie byli informowani o celu ba- 
dania i sposobu wykorzystania wyników. Następnie badani wypełniali arkusze złożone ze trzech skal, tj. ESSBS, TAB oraz arkusz personalny. Przeciętnie czas wypełniania arkuszy wynosił 20 minut. Uczestnictwo w badaniu było dobrowolne i nieodpłatne.

\section{Osoby badane}

W badaniu wzięło udział 144 uczniów szkół podstawowych znajdujących się $\mathrm{w}$ województwie małopolskim. W oryginalnej wersji narzędzie jest przeznaczone dla uczniów w wieku 11-13 lat (Aypay 2011). Z tej przyczyny zdecydowano się na badanie tylko uczniów, którzy mieli 11 lat. Osoby badane uczęszczały do $\mathrm{V}(\mathrm{N}=63)$ i VI $(\mathrm{N}=81)$ klasy szkoły podstawowej. W badaniach wzięło udział 75 dziewcząt i 69 chłopców.

\section{Wyniki}

W tabeli 1 zamieszczono statystyki opisowe polskiej wersji skali ESSBS, obliczone dla całej próby. Wskaźniki skośności i kurtozy w analizowanej metodzie przyjmowały wartościsatysfakcjonujące, nie przekraczając jedności. Wyniki takie pozwalają stwierdzić brak odchylenia od rozkładu normalnego. Jednak rezultaty uzyskane przy zastosowaniu testu Shapiro - Wilka wskazują na brak zgodności wyników w podskali BFF i z rozkładem normalnym $(\mathrm{p}<0,01, \mathrm{p}<0,001)$.

Tabela 1. Statystyki opisowe uzyskane w badanej grupie w skali wypalenia szkolnego

\begin{tabular}{|l|c|c|c|c|c|c|c|c|}
\hline $\begin{array}{c}\text { Nazwa } \\
\text { skali }\end{array}$ & M & SD & Min. & Max. & Skośność & Kurtoza & $\begin{array}{c}\text { Test } \\
\text { Shapiro- } \\
\text { Wilk }\end{array}$ & $\mathrm{p}$ \\
\hline BSA & 31,60 & 5,99 & 16,00 & 46,00 &,- 295 &, 072 &, 984 &, 083 \\
\hline BFF & 13,47 & 3,36 & 5,00 & 20,00 &,- 163 &,- 329 &, 982 &, 055 \\
\hline IIS & 10,74 & 2,74 & 4,00 & 16,00 &,- 123 &,- 559 &, 976 &, 013 \\
\hline LIS & 13,08 & 2,49 & 7,00 & 19,00 &,- 589 &,- 215 &, 937 &, 000 \\
\hline ESSBS & 68,90 & 11,05 & 40,00 & 97,00 &,- 092 &, 031 &, 993 &, 740 \\
\hline
\end{tabular}

Legenda: BSA - Wyczerpanie aktywnościami szkolnymi; BFF - Wypalenie związane z presją rodziców, LIS - Utrata zainteresowania szkołą; IIS - Niedopasowanie do wymogów szkolnych, ESSBS Ogólny poziom wypalenia szkolnego

Źródło: opracowanie własne. 


\section{Poziom wypalenia w badanej grupie uczniów}

Prezentacja poziomu wypalenia $\mathrm{w}$ grupie badanych uczniów bazowała na wynikach analizy skupień metodą k średnich. Ukazane różnice między wyłonionymi grupami zamieszczono $\mathrm{w}$ tabeli 2 .

Zastosowana statystyka umożliwiła wyłonienie 4 grup osób badanych zróżnicowanych pod względem wskaźników syndromu wyczerpania sił. Wszystkie grupy różnią się na poziomie istotnym poziomem ogólnego wypalenia oraz nasileniem wyczerpania aktywnościami szkolnymi. Grupą, która w największym stopniu doświadcza wypalenia jest grupa 4. Najmniej wypaleni byli uczniowie z grupy 2. Pierwszą grupę tworzą dzieci, które uzyskały najwyższe wskaźniki $\mathrm{w}$ skali wyczerpanie $\mathrm{z}$ uwagi na presję rodziców oraz niedopasowania do wymogów szkolnych $(\mathrm{N}=37)$. Druga grupa to uczniowie silnie zaangażowani w aktywności szkolne. Dane wskazują, że ta grupa uczniów w najmniejszym stopniu doświadcza wypalenia sił $(\mathrm{N}=23)$. Uczniowie z grupy 3 prezentują przeciętny stosunek do szkoły i średni poziom uczestnictwa w życiu szkolnym $(\mathrm{N}=53)$. Ostatnią grupę tworzą uczniowie w największym stopniu doświadczający wypalenia z nasilonym poczuciem wyczerpania sił $(\mathrm{N}=31)$. Zaprezentowane powyżej wyniki sugerują, że w grupie uczniów ze szkół podstawowych można wyróżnić dwa typy wypalenia różniące się nasileniem doświadczanych trudności z uwagi na wzmożone wymogi stawiane uczniom przez rodziców oraz brak zgodności między wymaganiami edukacyjnymi a zainteresowaniami samych uczniów.

\section{Struktura czynnikowa polskiej wersji skali ESSBS}

W celu ustalenia struktury wypalenia szkolnego w grupie polskich uczniów przeprowadzono eksploracyjną analizę czynnikową metodą głównych składowych z rotacją Oblimin i normalizacją Kaisera (do obliczeń wykorzystano pakiet SPSS Statistics 21). Adekwatność doboru próby sprawdzano poprzez zastosowanie test Kaisera-Mayera-Olkina i testu sferyczności Bartletta. Test KMO dla próby wyniósł 0,806, co jest wartością uprawniającą do wniosku, że struktura wewnętrzna skali była wyraźna i rzetelna (Hadi i in. 2016). Wyniki testu sferyczności Bartletta $\left(\chi^{2}(325)=1365,094, p<.0000\right)$ wskazują, że macierz wariancji-kowariancji nie była macierzą sferyczną (Yong Pearce 2013). Wartości obu mierników adekwatności doboru próby potwierdzają zasadność zastosowania analizy EFA na zebranych danych. Wyniki eksploracyjnej analizy czynnikowej zaprezentowano w tabeli 3. 


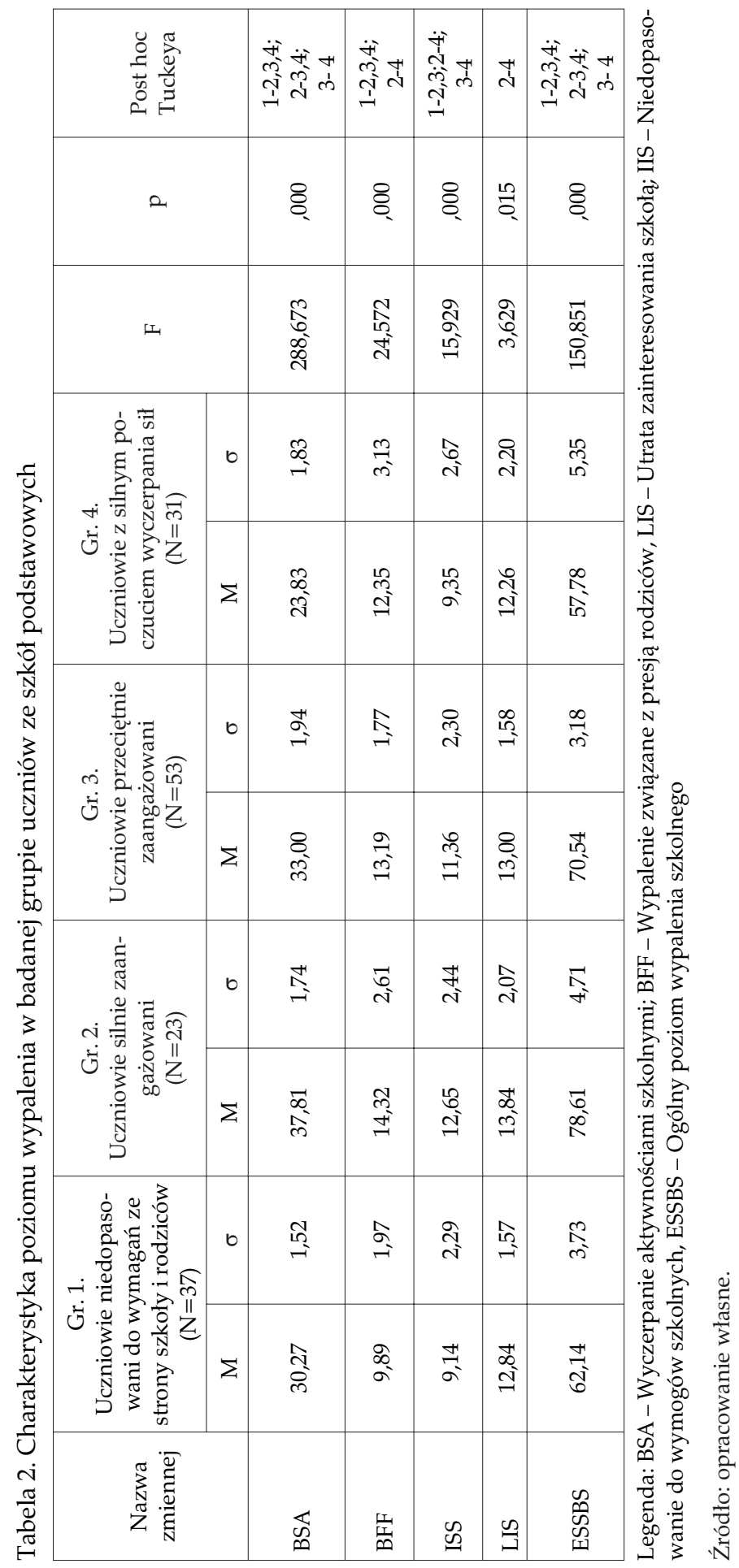


Tabela 3. Struktura czynnikowa skali ESSBS w badaniach dzieci ze szkoły podstawowej

Wyczerpanie

aktywnościami szkolnymi (BSA)
Nazwa skali

Niedopasowanie do wymogów szkolnych (IIS) (BFF)

Utrata zainteresowania szkołą (LIS)

\section{Całkowity \% wyjaśnionej wariancji} $49 \%$

$\alpha$ Cronbacha , 87

Źródło: opracowanie własne.

W analizie wyodrębnione zostały cztery czynniki, które zasadniczo odpowiadają czterem skalom z wersji oryginalnej narzędzia. W polskich badaniach uzyskano porównywalne do badań oryginalnych, ładunki czynnikowe. Cztery 
składowe wyjaśniają łącznie 49\% wariancji. Procent wyjaśnionej zmienności wyników dla czynnika I wynosi 25,5\% wariancji. Czynnik ten odpowiada wyróżnionej w oryginalnej wersji skali Wyczerpanie Aktywnościami Szkolnymi (BSA), a rozpiętość ładunków w poszczególnych pytaniach wynosi od 0.16 (item 6) do 0.76 (item 16). Mediana dla ładunków w pierwszym czynniku wyniosła 0.59. Drugi czynnik wyjaśnia 10\% wariancji i odpowiada oryginalnej skali Niedopasowanie do wymogów szkolnych (IIS). Rozpiętość wysokości ładunków czynnikowych w poszczególnych itemach wynosi od 0.39 (item 8) do 0.77 (item 12). Mediana dla ładunków w drugim czynniku wyniosła 0.75 . Trzeci czynnik wyjaśnia 7,5\% wariancji, odpowiada wyróżnionej skali Wypalenie związane z presją rodziców (BSF).Wyniki ładunków czynnikowych dla pytań wahają się między 0.35 (item 5) a 0.81 (item 23). Mediana dla ładunków w pierwszym czynniku wyniosła 0.69. Czwarty czynnik wyjaśnia 6\% zmienności wyniku.Rozpiętość ładunków wyniosła od 0.56 (item 13) do 0.80 9item, 19). Mediana dla ładunków wyniosła 0.67. W przeprowadzonej analizie czynnikowej trzy pytania (itemy 6,9, 8) ładowały, $\mathrm{w}$ większym stopniu inny czynnik, niż zakładano w oryginalnej wersji.Jedno pytanie w całym teście miało niższy ładunek czynnikowy niż wymagany w kryteriach psychometrycznych (item 9).

Rzetelność polskiej wersji skali ESSBS w badaniach dzieci w wieku szkolnym

Przeprowadzona analiza rzetelności polskiej wersji skali ESSBS $\mathrm{w}$ grupie dzieci ze szkoły podstawowej potwierdza wysoką spójność wewnętrzną narzędzia (tab. 2). Rzetelność dla całej skali była wysoka i wyniosła $\alpha=, 87$. Wysokość wskaźnika alfa Cronbacha w poszczególnych podskalach również była zadowalająca i wahała się od 0.68 (ISS) do 0.80 (BSA).

Trafność skali ESSBS w badaniach dzieci w wieku szkolnym

Trafność wewnętrzna. Analiza macierzy interkorelacji przeprowadzona na wynikach osób badanych $(\mathrm{N}=144)$ skali ESSBS i jej podskalzasadniczopotwierdza trafność wewnętrzną narzędzia (tab. 4).

Wszystkie podskale korelują na poziomie wysokim lub bardzo wysokim z ogólnym wynikiem w skali (współczynniki r Pearsona mieszczą się w przedziale 0,69 do 0,92).Jedyną nieistotną korelacje odnotowano między podskalą Niedopasowanie do wymogów szkolnych (IIS) a podskalą Utrata zainteresowania szkołą (LIS). 
Tabela 4. Interkorelacje pomiędzy skalami ESSBS uzyskane w polskich badaniach

\begin{tabular}{|l|c|c|c|c|c|}
\hline & BSA & BFF & IIS & LIS & ESSBS \\
\hline BSA & - & & & & \\
\hline BFF &, $406^{* *}$ & - & & & \\
\hline IIS &, $443^{* *}$ &, $398^{* *}$ & - & & \\
\hline LIS &, $577^{* *}$ &, $278^{* *}$ &, 096 & - & \\
\hline ESSBS &, $905^{* *}$ &, $685^{* *}$ &, $630^{* *}$ &, $646^{* *}$ & - \\
\hline
\end{tabular}

Legenda: BSA - Wyczerpanie aktywnościami szkolnymi; BFF -Wypalenie związane z presją rodziców, LIS - Utrata zainteresowania szkołą; IIS - Niedopasowanie do wymogów szkolnych, ESSBS Ogólny poziom wypalenia szkolnego

Źródło: opracowanie własne.

Trafność zewnętrzna narzędzia została sprawdzona poprzez zastosowanie analiz porównawczych (test $t$ studenta oraz analiza wariancji ANOVA). Analizy te miały na celu określenie różnic w poziomie wypalenia uczniów w zależności od płci, klasy, do której uczęszczają, zainteresowań i jakości relacji rówieśniczych i rodzinnych. W dalszym etapie przeprowadzono analizy korelacyjne między wynikami ESSBS a patologicznym wzorem zachowania typu A/B mierzonym skalą TAB. Przeprowadzone analizy statystyczne (test $\mathrm{t}$ studenta) pokazują, że płeć oraz wiek nie różnicuje badanych pod względem poziomu syndromu wyczerpania sił. Nie odnotowano żadnych istotnych statystycznie różnic. W ramach analiz sprawdzono również, czy uczniowie deklarujący różny poziom funkcjonowania szkolnego różnią się poziomem wypalenia. Uzyskane dane wskazują, że osoby badane różniły się jedynie pod względem utraty zainteresowania szkołą. W grupie uczniów bardzo dobrych i dobrych odnotowano istotnie niższe wskaźniki tej zmiennej w porównaniu z uczniami przeciętnymi, słabymi i bardzo słabymi (tab. 5).

Tabela 5. Wypalenie szkolne a deklarowane funkcjonowanie w roli ucznia

\begin{tabular}{|c|c|c|c|c|c|c|c|c|c|}
\hline \multirow[t]{2}{*}{ Zmienne } & \multicolumn{2}{|c|}{$\begin{array}{l}\text { Bardzo dobry } \\
\text { i dobry uczeń } \\
\quad \mathrm{N}=48\end{array}$} & \multicolumn{2}{|c|}{$\begin{array}{c}\text { Przeciętny } \\
\text { uczeń } \\
\mathrm{N}=69\end{array}$} & \multicolumn{2}{|c|}{$\begin{array}{c}\text { Słaby i bardzo } \\
\text { słaby uczeń } \\
\text { N = } 29\end{array}$} & \multirow[t]{2}{*}{$\mathrm{F}$} & \multirow{2}{*}{$\mathrm{p}$} & \multirow{2}{*}{$\begin{array}{l}\text { Post - } \\
\text { hoc }\end{array}$} \\
\hline & M & $\mathrm{SD}$ & M & $\mathrm{SD}$ & M & SD & & & \\
\hline BSA & 31,23 & 4,73 & 32,73 & 4,16 & 30,81 & 5,75 & 2,288 & 105 & - \\
\hline BFF & 11,73 & 2,62 & 12,74 & 2,70 & 13,00 & 3,06 & 2,579 & ,079 & - \\
\hline IIS & 10,79 & 2,46 & 10,80 & 2,98 & 10,52 & 2,64 & 110 & 895 & - \\
\hline LIS & 13,77 & 2,01 & 12,75 & 1,55 & 12,37 & 1,88 & 6,859 & ,001 & $1-2,3$ \\
\hline ESSBS & 67,52 & 7,84 & 69,01 & 8,31 & 66,70 & 9,04 & ,918 & ,402 & - \\
\hline
\end{tabular}

Źródło: opracowanie własne. 
Ostatnią analizowaną zmienną była relacja między wynikami w skali ESSBS a wzorem zachowania typu A, tj. „niezdrowy styl reagowania”, będącym jednym z czynników ryzyka pojawienia się tego syndromu. Wykorzystana skala TAB pozwoliła na pomiar czterech wskaźników tego zachowania tj. rywalizacja, niecierpliwość, pośpiech i wrogość. Wyniki analiz korelacyjnych zamieszczono w tabeli 6. Uzyskane dane wskazują, że poziom ogólnego wypalenia szkolnego oraz wyczerpania aktywnościami szkolnymi, wypalenia związanego z presją rodziców o utraty zainteresowania szkołą wzrasta wraz z wyższymi wskaźnikami wzoru zachowania typu A (korelacje istotne ujemne o słabej sile). Jedyną zmienną, w której nie odnotowano żadnych istotnych związków z wypaleniem była niecierpliwość. Wypalenie z uwagi na presje rodziców wiązało się istotnie z wyższymi wskaźnikami pośpiechu i wrogości. Niedopasowanie do wymogów szkolnych korelowało jedynie z wyższymi wskaźnikami rywalizacji $(\mathrm{r}=-, 173, \mathrm{p}<0,05)$. Wyższym wskaźnikom utraty zainteresowania szkołą towarzyszyły istotnie wyższe wskaźniki rywalizacji i pośpiechu.

Tabela 6. Korelacje między wypaleniem szkolnym a wskaźnikami wzoru zachowania typu A $(\mathrm{N}=144)$

\begin{tabular}{|l|c|c|c|c|c|}
\hline \multicolumn{1}{|c|}{ Zmienne } & $\mathrm{R}$ & $\mathrm{N}$ & $\mathrm{P}$ & $\mathrm{W}$ & WZA \\
\hline BSA &,$- 264^{* *}$ &,- 119 &,$- 366^{* *}$ &,$- 280^{* *}$ &,$- 317^{* *}$ \\
\hline BFF &,- 071 &,- 078 &,$- 249^{* *}$ &,$- 187^{*}$ &,$- 183^{*}$ \\
\hline IIS &,$- 173^{*}$ &,- 063 &,- 073 &,- 040 &,- 104 \\
\hline LIS &,$- 193^{*}$ &,- 081 &,$- 250^{* *}$ &,- 026 &,$- 164^{*}$ \\
\hline ESSBS &,$- 277^{* *}$ &,- 135 &,$- 391^{* *}$ &,$- 240^{* *}$ &,$- 319^{* *}$ \\
\hline
\end{tabular}

*** $\mathrm{p},<001 \quad{ }^{* *} \mathrm{p},<01 \quad{ }^{*} \mathrm{p},<05$

Legenda: BSA - Wyczerpanie aktywnościami szkolnymi; BFF - Wypalenie związane z presją rodziców, IIS - Niedopasowanie do wymogów szkolnych, LIS - Utrata zainteresowania szkołą, ESSBS Ogólny poziom wypalenia szkolnego; WZA - Wzór zachowania typu A; R - Rywalizacja; N - Niecierpliwość; p - Pośpiech; W - Wrogość

Źródło: opracowanie własne.

Poziom wypalenia uczniów a styl reagowania uczniów w sytuacjach stresowych

Wyniki analizy statystycznej wskazują, że uczniowie prezentujący zróżnicowany poziom wypalenia mają zbliżony poziom niecierpliwości. Styl reagowania typu A i jego wskaźniki, tj. rywalizacja, pospiech oraz wrogość różnicuje grupę uczniów zaangażowanych (Gr 2) od dwóch wyłonionych grup uczniów wypalonych (Gr 1 i 4). Uczniowie zaangażowani (Gr 2) prezentują istotnie niższy poziom zachowań rywalizacyjnych niż uczniowie wypaleni z silnym poczuciem niedopasowania. Wskaźniki pośpiechu w działaniu i wrogości w tej grupie uczniów również 


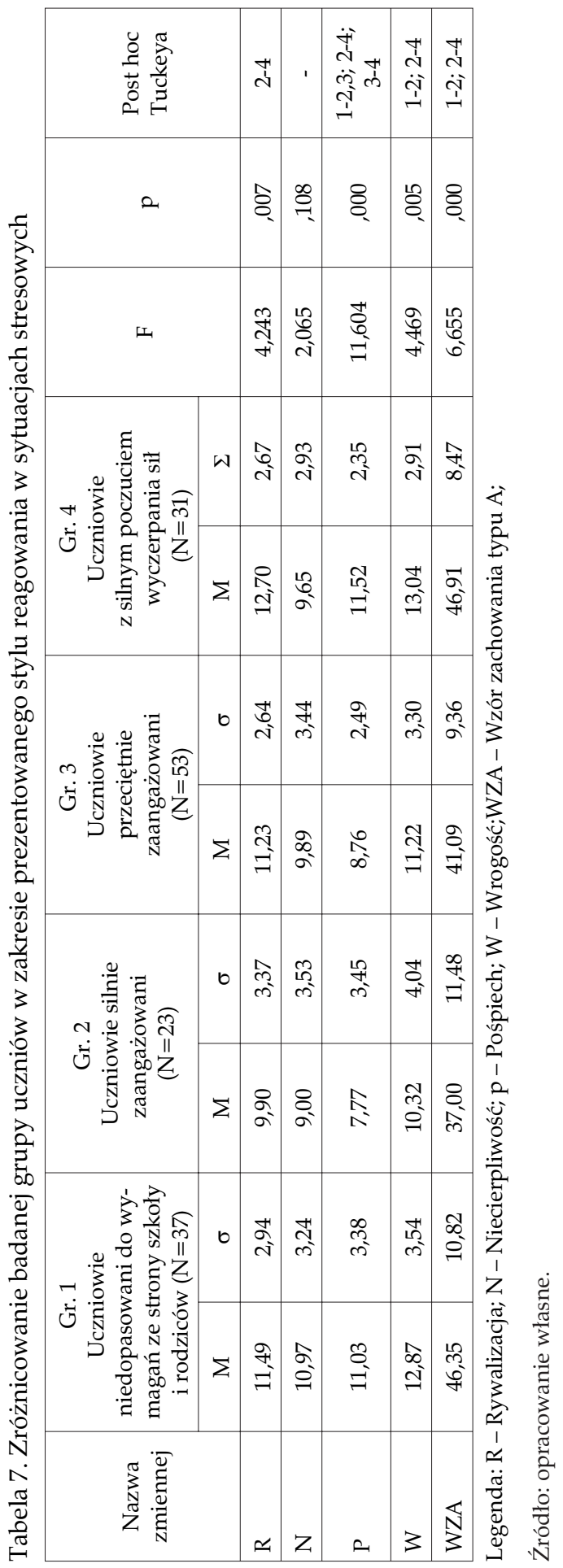


były istotnie niższe $\mathrm{w}$ grupie 2 niż $\mathrm{w}$ grupach 1 i 4 . Uczniowie o przeciętnym zaangażowaniu różnili się od uczniów wypalonych z grup 1 i 4 niższym poziomem pośpiechu w działaniu.

Wyniki jakie uzyskano, sugerują, że uczniowie wypaleni z jednej strony mają silne poczucie obciążenia obowiązkami szkolnymi, z drugiej żywią silne przeświadczenie, że muszą zdobywać, jak najwięcej celów (nierzadko w małym stopniu sprecyzowanych), w jak najkrótszym czasie (Ogińska-Bulik Juczyński 2010). Styl taki wiąże się nie tylko z częstym doświadczaniem stresu i negatywnymi emocjami, ale też z tłumieniem przeżywanych napięć i nadmiernym poczuciem odpowiedzialności (Chodkiewicz 2005).

\section{Podsumowanie}

Głównym celem artykułu było przedstawienie wyników prac walidacyjnych nad polską adaptacją skali wypalenia szkolnego ESSBS, prowadzonych na grupie uczniów ze szkół podstawowych. Analizy potwierdziły czteroelementową strukturę syndromu wypalenia. Uzyskane dane wskazują na metodologiczne trudności dotyczące jedynie 3 pytań, które ładowały w większym stopniu inną skalę niż zakładano. Dane jakie uzyskano uprawniają do wniosku, że skala ESSBS spełnia podstawowe kryteria dotyczące rzetelności i trafności. Wskaźnik zgodności wewnętrznej dla całej skali jest wysoki (á $=.87$ ). Analiza mocy dyskryminacyjnej pytań wykazała, że tylko dwie pozycje skali cechuje niska moc dyskryminacyjna. Weryfikacja założeń skali ESSBS w badanej grupie obejmowała sprawdzenie, czy skala dobrze różnicuje badaną grupę uczniów. W ramach prac walidacyjnych sprawdzono różnice w poziomie wypalenia w zależności od płci i klasy, do której uczęszczali badani. Wyniki jakie uzyskano, wskazują, że te charakterystyki nie różnicują badanych uczniów ze szkół podstawowych. Jednocześnie uczniowie o różnym poziomie funkcjonowania szkolnego, różnili się pod względem poziomu zainteresowania szkołą. W grupie uczniów bardzo dobrych i dobrych odnotowano istotnie niższe wskaźniki utraty zainteresowania szkołą w porównaniu z uczniami przeciętnymi, słabymi i bardzo słabymi. Wynik taki wydaje się potwierdzać dotychczasowe ustalenia teoretyków wypalenia.

Autorzy tj. R. Golembiewski, czy C. Maslach ujmują syndrom wyczerpania sił w kategoriach procesu, o swoistej dynamice i zróżnicowanym nasileniu Robert T. Golembiewski (Tucholska 2009) w swoim fazowym modelu akcentuje, że na początku procesu wypalenia pojawia się u jednostki cyniczne nastawienie do otoczenia (pierwotnie określane jako depersonalizacja). W klasycznych ujęciach wypalenia, tj. Ch. Maslach i M. Leiteraten wymiar definiowany jest jako zdystanso- 
wana postawa wobec podejmowanych aktywności (pracy, a w przypadku wypalenia szkolnego uczenie się), ale też jako chłód i obojętność wobec osób, z którymi się te aktywności realizuje (klienci, podopiecznie, a w przypadku wypalenia szkolnego nauczyciele i koledzy z klasy) (Chirkowska-Smolak 2009).Utrata Zainteresowania Szkołą odzwierciedla negatywną postawę wartościującą względem szkoły, uznanie jej za miejsce nudne, zaś nabywaną w placówce wiedzę za nieprzydatną (Aypay 2011). Wydaje się zatem, że na etapie szkoły podstawowej $\mathrm{w}$ badanej grupie uczniów dominuje właśnie ten pierwszy wymiar syndromu wypalenia.

Zdaniem P.D. Parker i K. Salmeli-Aro (2011) ten pierwszy etap wypalenia odzwierciedlaj nieefektywne radzenie sobie ucznia z doświadczanymi trudnościami. Jak pokazują badania, na kolejnych etapach edukacji brak angażowania się w aktywności szkolne rozszerza się obejmując sferę autoewaluacji. Wypalona młodzież gimnazjalna przejawiała istotnie wyższe wskaźniki niezadowolenia z własnej aktywności i poczucia braku umiejętności i niskich kompetencji, niż młodzież zaangażowana (Tomaszek Muchacka-Cymerman 2018). Warto w tym miejscu dodać, że wyniki jakie uzyskano sugerują, że pierwszym krokiem w oddziaływaniach prewencyjnych jest stwarzanie warunków, w których uczniowie są zainteresowani nabywaną wiedzą. Aby zapobiec utracie zainteresowań szkołą należy dbać o klimat klasy, który, jak stwierdzają J. Pietarinen i in. (2014), sprzyjać ma uczeniu się dzieci i uzyskiwaniu przez nich lepszych efektów. Autorzy w swoich badaniach stwierdzili, że dobre samopoczucie w szkole przyczynia się do zaangażowania poznawczego uczniów, a także do ich osiągnięć szkolnych. Wyniki pokazały, że zaangażowanie poznawcze uczniów związane było z ich dynamiczną interakcją ze środowiskiem szkolnym. Dobre samopoczucie uczniów w szkole było motywatorem do nauki. Również bardzo ważna jest osoba nauczyciela, która dba o właściwy klimat klasy. P. Jennings i M. Greenberg (2009) zaproponowali model klasy prospołecznej, w której znaczenie mają przede wszystkim kompetencje społeczne i emocjonalne nauczycieli orazrozwijanie i utrzymywanie wspierających relacji nauczyciel-uczeń, skuteczne zarządzanie klasą. Autorzy podkreślają jak istotne są umiejętności społeczne oraz kompetencje nauczycieli w odniesieniu do wyników uczniów.

Trafność narzędzia potwierdzają również istotne korelacje między wskaźnikami wzorca zachowania typu A. Jak zauważają Tomaszek i Muchacka-Cymerman (2018), znaczenie WZA dla pojawienia syndromu wypalenia związane jest z dominacją u jednostki potrzeby odnoszenia sukcesu i rywalizacyjnemu nastawieniu $\mathrm{w}$ sytuacji pojawienia się wymagań ze strony otoczenia.

Drugim celem artykułu było zbadanie poziomu wypalenia szkolnego w grupie uczniów ze szkół podstawowych. Wyniki analizy skupień pozwoliły na wyłonienie czterech grup uczniów w różnym stopniu doświadczających syndromu wy- 
palenia. W grupie pierwszej znaleźli się uczniowie wypaleni, mający poczucie silnego niedopasowania do stawianych im przez szkołę i rodziców wymogów $(\mathrm{N}=$ 37). Grupa uczniów silnie zaangażowanych liczyła 23 osoby (Gr 2). Najliczniejszą grupą byli uczniowie mający przeciętny poziom analizowanych zmiennych (Gr3, $N=53)$. Grupę tę nazwano uczniowie przeciętnie zaangażowani. Ostatnią grupę tworzyli uczniowie w znacznym stopniu odczuwający wyczerpanie sił. Analizy wykazały, że prawie połowa przebadanych uczniów zmaga się z wyczerpaniem sił (Gr 1 i Gr 4, 47\%). Stosunkowo liczna grupa uczniów doświadczających w różnym aspekcie syndromu wyczerpania sił potwierdza zasadność prowadzenia dalszych badań w tej grupie wiekowej. Jednocześnie jednoznacznie wskazuje na konieczność wprowadzania już na etapie szkoły podstawowej skutecznych programów przeciwdziałania powstawaniu i/lub rozwijaniu się tego syndromu.

Ostatnim celem prezentowanych analiz było określenie czy grupy różniące się poziomem wypalenia szkolnego prezentują odmienne wzorce zachowania związanego z odczuwaną presją (WZA). Uzyskane wyniki sugerują, że uczniów silnie zaangażowanych $\mathrm{w}$ aktywności szkolne różni od uczniów doświadczających syndromu wypalenia ogólny wzorzec zachowań typu A, zwłaszcza pośpiech i wrogość.Zaprezentowanedoniesienia badawcze jednoznacznie wskazują, że istnieje potrzeba aktywnego wspierania uczniów, silnie skoncentrowanych na uzyskiwaniu sukcesów edukacyjnych. C.E. Thoresen, M. Friedman, J.K. Gill, D.K. Ulmer (Czajkowski 2017). zauważają, że w grupie osób z podwyższonymi wskaźnikami WZA szczególnie ważne jest organizowaniu procesu zmian poprzez modyfikację: obronnej tendencji do kontrolowania otoczenia, wrogich i rywalizacyjnych nastawień, nadmiernego pobudzenia oraz ukrytej wrogości z towarzyszącą jej irytacją i złością. Efektywne programy profilaktyczne, które wykorzystywano w grupie osób dorosłych, nastawione były głównie na wykorzystanie behawioralnych technik, opartych o model społecznego uczenia się (Czajkowski 2017). Należy zauważyć, że oprócz eliminacji wrogich nastawień oraz nierealistycznej ocenie własnych możliwości, $w$ ramach działań przedstawiano alternatywne zachowania sprzyjające zdrowiu psychicznemu i ćwiczeniu bardziej adaptacyjnych i prospołecznych mechanizmów radzenia sobie z presją (Fares i in. 2016). W oddziaływaniach profilaktycznych $\mathrm{w}$ tym obszarze pomocne jest również promowanie osobistego zaangażowania (nauczycieli i uczniów) (Fares i in. 2016).

\section{Ograniczenia przeprowadzonych badań}

Zaprezentowane wyniki badań prowadzone była na stosunkowo niewielkiej próbie badawczej $(\mathrm{N}=144)$. Z tej uwagi wymagają replikacji obejmującej ogólnopolską i reprezentatywną grupę dla populacji uczniów ze szkół podstawowych. Ważne jest, by w badaniach uwzględniono wyniki uczniów nie tylko mających 
ukończone 11 lat, ale również młodszych (10 lat), którzy uczęszczają do klas 5. Wyniki analiz statystycznych dotyczących zastosowania skali ESSBS w tej grupie wiekowej, warto uzupełnić o konfirmacyjną analizę czynnikową. Dalsze badania powinny powinny zweryfikować, czy płeć faktycznie nie różnicuje osób badanych. Tym bardziej, że dotychczasowe badania prowadzone na grupie młodzieży gimnazjalnej, licealnej i akademickiej wskazują na istotne powiązania między płcią osób badanych a poziomem doświadczanego wyczerpania (Salmela-Aro Tynkkynen 2012).

\section{Przyszłe badania}

Niniejsze wyniki badań stanowią wstęp do dalszych prac badawczych w tej grupie wiekowej. Interesujące jest, czy badania, które wykazały, że większe obciążenie pracą powoduje większe wypalenie zawodowe zarówno w sferze emocjonalnej, w sferze depersonalizacji, jak i w sferze zmniejszenia osobistego spełnienia (Greenglass 2001) będą również pozytywnie korelowały w odniesieniu do sytuacji uczniów w szkole. Warto podjąć badania, które pozwolą na identyfikację czynników intrapersonalnych i interpersonalnych, mających wpływ na wypalenie zawodowe, oraz wyprowadzić z tych badań wnioski na temat wsparcia mającego na celu zapobieganie i zmniejszanie wypalenia szkolnego u uczniów. Z uwagi na małą ilość badań w tym obszarze na gruncie polskim, warto przeprowadzić badania longituidalne, mające na celu sprawdzenie, jaka jest dynamika wypalenia w grupie polskich uczniów. Tym bardziej, że zjawisko wypalenia ma ścisły związek z czynnikami kulturowymi i może w odmienny sposób przebiegać w zależności od specyfiki środowiska szkolnego. Otwarte pozostaje również pytanie o efektywność pracy uczniów wypalonych i niewypalonych, na które warto poświęcić czas w kolejnych badaniach.

\section{Bibliografia}

Aypay A. (2011), Elementary School Student Burnout Scale for Grades 6-8: A Study of Validity and Reliabilit, Educational Sciences: Theory \& Practice, 11(2).

Aypay A. (2012), Secondary School Burnout Scale (SSBS), Educational Science: Theory \& Practice, $12(2)$.

Charkowska-Smolak T. (2009), Organizacyjne czynniki wypalenia zawodowego, Ruch Prawniczy, Ekonomiczny i Socjologiczny, t. LXXI, 4.

Chodkiewicz J. (2005), Psychologia zdrowia. Wybrane zagadnienia, WSHE, Łódź.

Czajkowski W. (2017), Psychologia bezpieczeństwa. Wyzwania i zagrożenia, Apeiron, Kraków.

Fares J., Al Tabosh H., Saadeddin Z., El Mouhayyar Ch., Aridi H. (2016), Stress, Burnout and Coping Strategies in Preclinical Medical Students, North American Journal of Medical Sciences, 8(2).

Fengler J. (2001), Pomaganie męczy - wypalenie w pracy zawodowej, GWP, Gdan?sk. 
Friedman M., Rosenman R. (1974), Type A behavior and your heart, Knopf, New York.

Greenglass E.R., Burke R.J., Fiksenbaum L. (2001), Workload and burnout in nurses, Journal of Community and Applied Social Psychology, 11.

Hadi N.U., Abdullah N., Sentosa I. (2016), An Easy Approach to Exploratory Factor Analysis: Marketing Perspective, Journal of Educational and Social Research, 6(1).

Jennings P.A., Greenberg M.T. (2009), The Prosocial Classroom: Teacher Social and Emotional Competence in Relation to Student and Classroom Outcomes, Review of Educational Research, 79(1).

Juczyński Z., Ogińska-Bulik N. (2009), Narzędzia pomiaru stresu i radzenia sobie ze stresem, Pracownia Testów Psychologicznych, Warszawa.

Kirenko J., Zubrzycka-Maciąg T. (2011), Wspótczesny nauczyciel. Studium wypalenia zawodowego, Wydawnictwo UMCS, Lublin.

Kraczla M. (2013), Wypalenie zawodowe jako efekt dtugotrwałego stresu, Zeszyty Naukowe Wyższej Szkoły Humanitas. Zarządzanie, 14(2).

Maslach C., Jackson S. E., Leiter M. P. (1997), Maslach Burnout Inventory: Third edition [w:] C.P. Zalaquett, R.J. Wood (eds.), Evaluating stress: A book of resources, Scarecrow Press, Lanham.

Maslach Ch., Jackson S.E. (1981), The measurement of experienced burnout, Journal of Occupational Behavior, 2.

Maslach Ch. (2000), Wypalenie w perspektywie wielowymiarowej [w:] H. Sęk (red.), Wypalenie zawodowe. Przyczyny. Mechanizmy. Zapobieganie, PWN, Warszawa.

Maslach Ch., Leiter M.P. (2011), Prawda o wypaleniu zawodowym. Co zrobić ze stresem organizacji, PWN, Warszawa.

Ogińska-Bulik N., Juczyński Z. (2010), Osobowość stres a zdrowie, Difin, Warszawa.

Parker P.D., Salmela-Aro K. (2011), Developmental processes in school burnout: A comparison of major developmental models, Learning and Indyvidual Diofferences, 21(2).

Pietarinen J., Soini T., Pyhältö C. (2014), Students' emotional and cognitive engagement as the determinants of well-being and achievement in school, International Journal of Educational Research, 67.

Pines A.M., Aronson E. (1988), Career burnout: Causes and cures, Routledge, New York.

Pines A.M. (2000), Wypalenie - w perspektywie egzystencjalnej [w:] H. Sęk (red.), Wypalenie zawodowe. Przyczyny, mechanizmy, zapobieganie, Państwowe Wydawnictwo Naukowe, Warszawa.

Pines A.M. (2011), Wypalenie w perspektywie egzystencjalnej [w:] H. Sęk (red.), Wypalenie zawodowe. Przyczyny i zapobieganie, Państwowe Wydawnictwo Naukowe, Warszawa.

Przewłocka J. (2015), Klimat szkoły i jego znaczenie dla funkcjonowania uczniów w szkole. Raport o stanie badań, Instytut Badań Edukacyjnych, Warszawa.

Salmela-Aro K., Tynkkynen L. (2012), Gendered pathways in school burnout among adolescents, Journal of Adolescence, 35.

Sęk H. (2000), Uwarunkowania i mechanizmy wypalenia zawodowego w modelu społecznej psychologii poznawczej [w:] H. Sęk (red.), Wypalenie zawodowe. Przyczyny, mechanizmy, zapobieganie, Państwowe Wydawnictwo Naukowe, Warszawa.

Talik E. (2011), Specyfika stresu szkolnego i strategie radzenia sobie z nim przez młodzież w okresie dorastania, Horyzonty Psychologii, 1(1). 
Tomaszek K., Muchacka-Cymerman A. (2018b), Radzenie sobie ze stresem i patogenny wzór zachowania A jako predyktory wypalenia szkolnego uczniów, Teraźniejszość - Człowiek - Edukacja, t. 21, 3(83).

Tomaszek K., Muchacka-Cymerman A. (2019), Polish adaptation of the ESSBS school burnout scale: pilot study results, Hacettepe University Journal of Education.

Tucholska S. (2009), Wypalenie zawodowe u nauczycieli. Psychologiczna analiza zjawiska i jego osobowościowych uwarunkowań, wyd. 2 popr., Wydawnictwo KUL, Lublin.

Yong A.G., Pearce S. (2013), A Beginner's Guide to Factor Analysis: Focusing on Exploratory Factor Analysis, Tutorials in Quantitative Methods for Psychology, 9(2). 